\title{
Hypoxia Inducible-Factor $1 \alpha$ Regulates the Metabolic Shift of Pulmonary Hypertensive Endothelial Cells
}

Iwona Fijalkowska, ${ }^{* \dagger}$ Weiling $\mathrm{Xu},{ }^{\ddagger \S}$ Suzy A.A. Comhair, ${ }^{\ddagger \S}$ Allison J. Janocha, ${ }^{\ddagger \S}$ Lori A. Mavrakis, ${ }^{\ddagger \S}$ Balaji Krishnamachary, ${ }^{\text {" }}$ Lijie Zhen, ${ }^{*}$ Thianzi Mao, ${ }^{*}$ Amy Richter, ${ }^{*}$

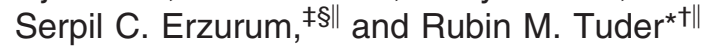
From the Division of Cardiopulmonary Pathology," Department of Pathology, the Division of Pulmonary and Critical Care Medicine, ${ }^{\dagger}$ Department of Medicine, and the Department of Radiology, "Johns Hopkins University School of Medicine, Baltimore, Maryland; the Departments of Pathobiology, ${ }^{\ddagger}$ and Pulmonary, Allergy and Critical Care Medicine, $\$$ The Cleveland Clinic, Cleveland, Obio; and the Pulmonary Vascular Research Institute, Canterbury, United Kingdom

Severe pulmonary hypertension is irreversible and often fatal. Abnormal proliferation and resistance to apoptosis of endothelial cells (ECs) and hypertrophy of smooth muscle cells in this disease are linked to decreased mitochondria and preferential energy generation by glycolysis. We hypothesized this metabolic shift of pulmonary hypertensive ECs is due to greater hypoxia inducible-factor $1 \alpha$ (HIF-1 $\alpha$ ) expression caused by low levels of nitric oxide combined with low superoxide dismutase activity. We show that cultured ECs from patients with idiopathic pulmonary arterial hypertension (IPAH-ECs) have greater HIF-1 $\alpha$ expression and transcriptional activity than controls under normoxia or hypoxia, and pulmonary arteries from affected patients have increased expression of HIF- $1 \alpha$ and its target carbonic anhydrase IX. Decreased expression of manganese superoxide dismutase (MnSOD) in IPAH-ECs paralleled increased HIF-1 $\alpha$ levels and small interfering (SI) RNA knockdown of MnSOD, but not of the copper-zinc SOD, increased HIF-1 protein expression and hypoxia response element (HRE)-driven luciferase activity in normoxic ECs. MnSOD siRNA also reduced nitric oxide production in supernatants of IPAH-ECs. Conversely, low levels of a nitric oxide donor reduced HIF-1 $\alpha$ expression in normoxic IPAH-ECs. Finally, mitochondria numbers increased in IPAH-ECs with knockdown of HIF-1 $\alpha$. These findings indicate that alterations of nitric oxide and MnSOD contribute to pathological HIF- $1 \alpha$ expression and account for lower numbers of mitochondria in IPAH-ECs. (Am J Pathol 2010, 176:1130-1138; DOI: 10.2353/ajpath.2010.090832)

Severe pulmonary arterial hypertension is characterized by significant increases in pulmonary artery pressures to levels present in the systemic circulation. Pulmonary hypertension $(\mathrm{PH})$ is a major determinant of morbidity and mortality in several pulmonary and heart diseases. The pathogenesis of severe pulmonary arterial hypertension has revolved around excessive vasoconstriction and/or abnormal pulmonary vascular remodeling. Recent experimental evidence has linked the pulmonary vascular disease in severe pulmonary arterial hypertension to an abnormal proliferative vascular cell phenotype, which is also characterized by resistance to endothelial and/or vascular smooth muscle cell apoptosis. ${ }^{1}$ The identification that there is a clonal expansion of endothelial cells (ECs) in idiopathic pulmonary arterial hypertension (IPAH) ${ }^{1}$ and somatic and germline mutations in the transforming growth factor $\beta$ superfamily, particularly of bone morphogenetic protein receptor $2,{ }^{2,3}$ led to the concept that this abnormal vascular cell proliferation process resembles that seen in neoplastic processes. ${ }^{4}$ The hypoxia-driven activation of hypoxia inducible factor (HIF), which contributes to several of the key features present in neoplastic processes, ${ }^{5}$ also plays a role in the pathogenesis of experimental pulmonary hypertension. ${ }^{6,7}$

$\mathrm{HIF}$, a heterodimer of the HIF- $1 \alpha$ or $-2 \alpha$, and HIF- $1 \beta$, mediates adaptive molecular responses to low oxygen availability, ${ }^{8}$ leading to transcriptional activation of genes

Supported by the NHLBI grants RO1HL60917 (to S.C.E.) and RC1HL100849 (to R.M.T.), American Heart Association (to R.M.T.), and the Pulmonary Hypertension Breakthrough Initiative of the Cardiovascular Medical Research Education Fund (to S.C.E. and R.M.T.).

I.F. and W.X. contributed similarly to this work; S.C.E. and R.M.T. are co-corresponding authors.

Accepted for publication November 5, 2009

Supplemental material for this article can be found on http://ajp. amjpathol.org

Address reprint requests to Rubin M. Tuder, M.D., 12700 East 19th Avenue, Research Complex 2, room 9001, Aurora, CO 80045. E-mail: Rubin.Tuder@UCDenver.edu. 
that regulate energy metabolism, erythropoiesis, vasomotor tone, and angiogenesis. ${ }^{9} \mathrm{HIF}-1 \alpha$ therefore plays a pathological role in tumor angiogenesis, neoplastic invasion, ${ }^{9}$ and in the metabolic shift of cancer cells toward glycolysis, which underlies the Warburg phenomena. ${ }^{10}$ HIF- $2 \alpha$ coordinates fetal lung development ${ }^{11}$ and adaptive lung responses to chronic hypoxia, which include the control of expression of genes involved in pulmonary vascular cell proliferation and angiogenesis. ${ }^{12}$ Identification of vascular endothelial growth factor, HIF- $1 \alpha$, and HIF1 $\beta$ expression within endothelial plexiform lesions ${ }^{13}$ and in pulmonary artery medial smooth muscle cells ${ }^{14}$ suggests that HIF-dependent signaling may contribute to the proliferative vasculopathy of IPAH. The potential pathogenic role of HIF- $1 \alpha$ in $\mathrm{PH}$ was supported by the findings that $\mathrm{HIF}-1 \alpha^{6}$ or $\mathrm{HIF}-2 \alpha^{7}$ heterozygous mice have decreased hypoxic $\mathrm{PH}$, when compared with littermates, and abnormalities in HIF- $1 \alpha$ underlie the mitochondria pathology and $\mathrm{PH}$ in the Fawn-Hooded rat model of spontaneous disease. ${ }^{14}$ The role of abnormal HIF-dependent signaling in human IPAH has not been addressed.

Our prior work indicated that cultured ECs derived from human IPAH lungs (IPAH-ECs) exhibit an abnormal metabolic phenotype that is characterized by low numbers of mitochondria and decreased oxygen consumption, significantly higher glycolytic rate ${ }^{15}$ apoptosis-resistance, and increased cell proliferation. ${ }^{16}$ Moreover, pulmonary and total body nitric oxide (NO) are lower in IPAH patients, as compared with healthy controls. ${ }^{17-21}$ Here, we hypothesize that IPAH-ECs have altered hypoxia sensing, with increased expression of $\mathrm{HIF}-1 \alpha$, which accounts for the decreased mitochondria in IPAH-ECs. ${ }^{15}$ Moreover, we postulate that the oxidative stress seen in IPAH lungs, ${ }^{22-25}$ caused by decreased expression of manganese superoxide dismutase and nitric oxide, accounts for the up-regulation of HIF- $1 \alpha$, and ultimately, for the decreased mitochondria numbers in IPAH-ECs. Our findings using disease-relevant cells provide the rationale for the development of therapies targeting the energetic shift and HIF-1 activation in pulmonary arterial hypertension.

\section{Materials and Methods}

\section{Clinical Characteristics}

IPAH patients were identified by the clinical classification of pulmonary hypertension, ${ }^{26}$ recently updated in the fourth World Symposium on Pulmonary Hypertension. ${ }^{27}$ Altogether, five IPAH and three control subjects were studied. Clinical characteristics among subjects were similar (age in years, IPAH $43 \pm 6$, control $29 \pm 12$; sex [female/male], IPAH 4/1, control 2/1; race [Caucasian/ African American/Hispanic], IPAH 5/0/0, control 3/0/0). Pulmonary hypertension was diagnosed by right heart catheterization performed for clinical care (pulmonary artery pressures [mm Hg], IPAH, systolic $88 \pm 3$, diastolic $37 \pm 4$, mean $59 \pm 3$ ). The study was approved by the Cleveland Clinic Institutional Review Board. The immunohistochemical studies were performed in histological sec- tions of IPAH $(n=5)$ or normal lungs $(n=5)$ (cases P1 to $P 5$, see table in ${ }^{28}$ ). These five patients were treated with intravenous prostacyclin before lung transplant. The study was approved by the Western Institutional Review Board (in lieu of the Johns Hopkins Institutional Review Board).

\section{Cell Culture}

Human pulmonary artery ECs were dissociated and cultured as described before ${ }^{16}$ in endothelial cell growth medium (EGM-2, Cambrex, Walkersville, MD) on plates precoated with fibronectin $1 \mu \mathrm{g} / \mathrm{cm}^{2}$ at $37^{\circ} \mathrm{C}$ for 1 hour. Cells were passaged at $70 \%$ to $80 \%$ confluence by dissociation from plates with $0.25 \%$ trypsin-EDTA (Invitrogen Corporation, Carlsbad, CA). Primary cultures of passages 5 to 8 were used in experiments. HeLa cells were maintained in Dulbecco's Modified Eagle Medium (Invitrogen Corporation) with $10 \%$ heat-inactivated fetal calf serum, and $1 \%$ penicillin/streptomycin. Human umbilical vein ECs (HUVECs) (Lonza, Walkersville, MD) were cultured in endothelial cell growth medium (EGM-2, Cambrex).

For nitric oxide (NO) donor treatment, cells were incubated with DETA NONOate (detaNO) (AXXORA LLC, San Diego, CA) as the time indicated. For hypoxia treatment, cells were placed directly in a $5 \% \mathrm{CO}_{2}$ and $95 \%$ air incubator $\left(21 \% \mathrm{O}_{2}\right)$ or exposed to hypoxia in a sealed chamber or a hypoxic incubator, and cultured at $37^{\circ} \mathrm{C}$.

\section{Western Blot}

Cytosolic and nuclear extracts of pulmonary artery ECs were prepared according to manufacturer's protocol (Panomics Inc, Fremont, CA). Whole cell lysates were prepared as previously described ${ }^{21}$ or in radioimmunoprecipitation assay buffer (Santa Cruz Biotechnology, Santa Cruz, CA). Protein was separated by electrophoresis on a $4 \%$ to $15 \%$ Tris- $\mathrm{HCl}$ precast gel (Bio-Rad Lab, Hercules, $\mathrm{CA}$ ), and then transferred onto polyvinylidene difluoride membranes (Millipore Corporation, Bedford, MA). Alternatively, XT Precast Gels (Bio-Rad) and 3-(N-morpholino) propanesulfonic acid buffer were used for SDS polyacrylamide gel electrophoresis. Antibodies used for Western analyses included mouse monoclonal antiHIF- $1 \alpha$ antibody (Ab) (BD Biosciences, Mississauga, ON, Canada), anti-catalase Ab (Sigma-Aldrich, St. Louis, MO), anti-Complex III-2 Ab (Molecular Probes, Inc., Eugene, OR), anti-cytochrome c Ab (Santa Cruz Biotechnology) rabbit polyclonal anti-manganese superoxide dismutase (MnSOD) Ab, anti-CuZnSOD Ab (Santa Cruz Biotechnology), anti-von Hippel-Lindau (VHL) Ab, antiprolyl hydroxylase 2 Ab (Novus Biologicals, Littleton, $\mathrm{CO}$ ), or anti-EC nitric oxide synthase (eNOS) Ab (Affinity Bioreagents, Golden, CO), followed by a secondary antirabbit or anti-mouse Ab (Amersham, Arlington Heights, IL, or Cell Signaling Technology, Beverly, MA). Goat polyclonal anti-lamin B Ab, rabbit polyclonal anti-enolase Ab, or mouse monoclonal anti- $\alpha$-tubulin Ab (Santa Cruz), antiglyceraldehyde phosphate dehydrogenase Ab (Re- 
search Diagnostics, Inc., Concord MA), and anti-tubulin Ab (Santa Cruz Biotechnology), were used for protein loading.

\section{VHL Gene Promoter Methylation Assay}

DNA was isolated and purified from IPAH-ECs and IPAH whole lung tissue specimens. The DNA was then bisulfite modified with Methyl Detector Bisulfite Modification Kit (Active Motif, Carlsbad CA). The positive control consisted of p16 ${ }^{\text {Kip } 1}$ methylation assessed by nested PCR, using primers included in the kit. Methylation status of the VHL promoter was assessed using the following primers $^{29}$ : unmethylated: forward (-185), 5'-GTTGGAGGATTTTTTTGTGTATGT-3', reverse (-20), 5'-CCCAAACCAAACACCACAAA- ${ }^{\prime}$, with an expected amplicon of $165 \mathrm{bp}$; and methylated: forward (-183), 5'-TGGAGGATTTTTTTGCGTACGC-3', reverse (-25), 5'-GAACCGAACGCCGCGAA-3', with expected amplicon of 158 bp. Methylated DNA and unmethylated DNA from Chemicon were used as positive and negative controls, respectively, in reactions run in parallel with sample DNA. The PCR protocol were as follows: $95^{\circ} \mathrm{C} \times 5$ minutes, $\left(95^{\circ} \mathrm{C} \times\right.$ 45 seconds, $59^{\circ} \mathrm{C} \times 45$ seconds, $72^{\circ} \mathrm{C} \times 60$ seconds) $\times$ $35,72^{\circ} \mathrm{C} \times 10$ minutes, followed by maintenance at $4^{\circ} \mathrm{C}$.

\section{Transient Transfection and Luciferase Assay}

Wild-type hypoxia response element (HRE)-luciferase reporter construct and mutant HRE-luciferase reporter construct were generous gifts from Dr. M.C. Simon. ${ }^{30}$ Both plasmids have three copies of HRE in tandem and cloned upstream of the Firefly luciferase gene in the $\mathrm{pGL} 2$ vector. According to the manufacturer protocol of Lipofectamine 2000 Reagent (Invitrogen Corp), IPAH-ECs, or control human pulmonary artery ECs were transiently transfected with wild-type or mutant constructs for 5 hours and cotransfected with Renilla luciferase construct for normalization of transfection efficiency. Alternatively, cells were transfected using Fugene6 (Roche Applied Science, Indianapolis, IN) or Targeting Systems (El Cajon, CA) instead of lipofectamine. In parallel experiments, enhanced green fluorescence protein was used to determine percentage of cells transfected. After transfection, cells were exposed to hypoxia with $2.5 \% \mathrm{O}_{2}$, treated with $125 \mu \mathrm{mol} / \mathrm{L} \mathrm{CoCl}_{2}$, or left untreated under normoxia $\left(21 \% \mathrm{O}_{2}\right) ; 48$-hour after transfection, cells were assayed for Western blot, luciferase activity using a Dual-Luciferase Reporter Assay System (Promega Corp, Madison, WI), and for protein content by Bradford method (BioRad Laboratories, Inc., Hercules, CA). Wild-type HRE-luciferase activity was determined by values of Firefly luciferase normalized by the Renilla luciferase activity, protein content, and mutant HRE-luciferase reporter construct activity. Fold-induction of HRE binding activation was the ratio of normalized HRE-luciferase activity under treatment with $\mathrm{CoCl}_{2}$ or hypoxia over the relative activity in cells exposed to normoxia.

\section{Immunohistochemistry}

Immunohistochemical detection of HIF- $1 \alpha$ was performed with the mouse anti-human HIF- $1 \alpha$ Ab (Novus Biol.) at 1:8000 dilution for 30 minutes at $37 \mathrm{C}$ using the Dako Cytomation CSA system for mouse antibodies (Dako). Histological sections of formalin-fixed, paraffinembedded lung tissues were dehydrated followed by antigen retrieval with a preheated citrate buffer (Dako). The sections were then blocked with avidin-biotin and then treated with $3 \% \mathrm{H}_{2} \mathrm{O}_{2}$ for 7 minutes. Following incubation with primary $A b$ or negative control (mouse lgG), the slides were incubated with the link $A b$ for 15 minutes, then with streptavidin-biotin for 15 minutes, and the biotinylated tyramide amplification reagent diluted $1: 10$ in $0.10 \mathrm{M}$ Tris. $\mathrm{HCl}, 0.15 \mathrm{M} \mathrm{NaCl}, 0.5 \%$ BMP blocking buffer. The secondary streptavidin-horseradish peroxidase was incubated for 15 minutes followed by development with diaminobenzidine. Carbonic anhydrase IX (CAIX) expression was detected with a rabbit anti-human CAIX (Novus Biol) at 1:500 dilution for 1 hour at room temperature. Histological sections of formalin-fixed, paraffin-embedded lung tissues were dehydrated and blocked with serum block for 30 minutes, followed by incubation with primary $\mathrm{Ab}$ or rabbit serum. The slides were then developed by the avidin-biotin system with diaminobenzidine as chromogen (Vector).

\section{MnSOD Small Interfering RNA}

MnSOD small interfering (si)RNA was synthesized by Ambion (Austin, TX). The sense and antisense MnSOD siRNA were 5'-GGAACAACAGGCCUUAUUCtt-3' (sense) and 5'-GAAUAAGGCCUGUUGUUCCtt-3' (antisense). SilencerTM Negative control \#1 siRNA (siRNA control) (Ambion, Austin TX) was used as a negative control. ${ }^{31}$

\section{SOD Activity}

SOD activity determined by the rate of reduction of cytochrome $c$ with one unit $(U)$ of SOD activity is defined as the amount of SOD required to inhibit the rate of cytochrome c reduction by $50 \%$.

\section{HIF-1 $\alpha$ Micro-RNA}

HIF-1 $\alpha$ micro (mi)RNA (AF304431) served as the target sequence. BLOCK-iT RNAi Designer from Invitrogen was used to design two single-stranded DNA oligonucleotides encoding the target pre-miRNA. The top and bottom strands were annealed to generate a double-stranded oligonucleotide suitable for cloning into BLOCK-iT Pol II miR RNAi Expression Vectors (pcDNA6.2-GW/EmGFP$\mathrm{miR}$ ). This vector contains enhanced green fluorescent protein coding sequence that allows visual delivery assessment. Overall 12 different constructs with doublestranded oligos were tested and pcDNA6.2-GW/EmGFPmiR-neg control plasmid (Invitrogen) which is predicted not to target any known vertebrate gene was used as a negative control. The most effective blocking sequence 
was selected by Dual-Luciferase Reporter Assay (Promega), based on the inhibition of HRE-luciferase activity. Percent inhibition was calculated according to the formula: $(A-B) / A \times 100 \%$, where $A=$ relative (fold) HREluciferase activity induced by $\mathrm{CoCl}_{2}$ or hypoxia in control vector transfected cells, B = relative (fold) HRE-luciferase activity induced by $\mathrm{CoCl}_{2}$ or hypoxia in $\mathrm{HIF-}-1 \alpha$ miRNA-transfected cells. The most potent silencing sequence used for further experiments targeted the sequence AGGATCAGACACCTAGTCCT (1483 to 1503) within $\mathrm{HIF}-1 \alpha$ mRNA, which had $54 \%$ to $75 \%$ inhibition of HRE-luciferase activity as determined for each cell line separately.

\section{Mitochondria Staining and Confocal Microscopy}

IPAH-ECs and control cells in chamber slides were transfected with HIF- $1 \alpha$ miRNA or control miRNA. Seventy-two hours following transfection, mitochondria were stained with Mitotracker Red 580 (Invitrogen). The slides were mounted with Vectashield mounting medium with 4',6diamidino-2-phenylindole (Vector Labs, Burlingame, CA), sealed, and analyzed by confocal laser-scanning microscopy (TCS-40; Leica Microsystems, Cambridge, UK).

\section{Southern Analysis}

As previously described, ${ }^{15}$ total DNA extracted from IPAH-EC was digested with restriction enzyme Pvull, electrophoresed through a $0.8 \%$ agarose gel, and transferred to Duralon-UV membranes (Stratagene, Cedar Creek, TX). The filters were hybridized with the ${ }^{32} \mathrm{P}$-labeled PCR generated mitochondrial DNA (mtDNA) probe and visualized with autoradiography.

\section{Statistical Analyses}

Data were shown as mean \pm SE. All statistical comparisons were performed using the Student's $t$-test, paired t-test, analysis of variance, or Wilcoxon nonparametric analyses as appropriate. The level of significance set at or below 0.05. All data were analyzed by the JMP 7 software (SAS Institute, Cary, NC).

\section{Results}

\section{Greater HIF-1 $\alpha$ Expression and Transcriptional Activity Found in IPAH-ECs and IPAH Lungs}

As HIF- $1 \alpha$ contributes to proliferative properties of neoplastic cells, ${ }^{5}$ is expressed in plexiform lesions in IPAH, ${ }^{13}$ and has been recently implicated in experimental pulmonary hypertension, ${ }^{14}$ we evaluated $\mathrm{HIF}-1 \alpha$ expression in the highly proliferative IPAH-ECs. HIF-1 $\alpha$ was expressed in cultured IPAH-ECs $(n=3)$ but not control ECs $(n=3)$ under normoxia (control: $1.00 \pm 0.14$ vs. IPAH: $1.49 \pm$ 0.27 , normalized relative expression levels, $n=10$ replicate experiments, Student's $t$-test, $P<0.05)$. IPAH-ECs had approximately twofold higher HIF-1 $\alpha$ expression un-
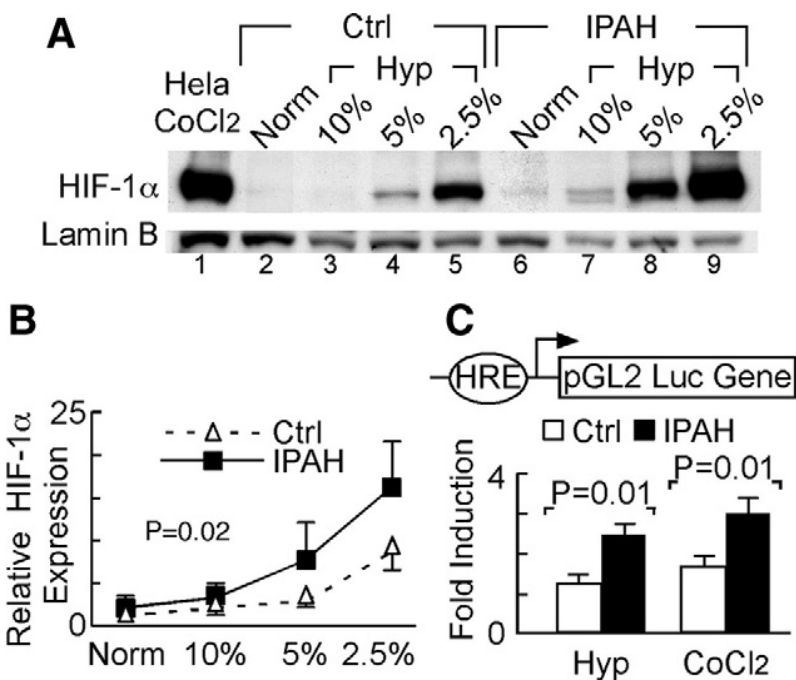

Figure 1. Enhanced HIF- $1 \alpha$ expression and transcriptional activity in IPAHECs. A: Representative Western blot analysis showing HIF- $1 \alpha$ expression in nuclear extracts of IPAH-ECs $(n=3)$ and control cells (Ctrl, $n=3)$ under normoxia (Norm) or under a range of hypoxia (Hyp) for 4 hours. B: Quantitative densitometric analysis of Western blots for HIF- $1 \alpha$ expression in nuclear extracts of IPAH-ECs $(n=3)$ and control ECs $(n=3)$. C: HIF- $1 \alpha$ luciferase reporter activity in cells, transiently transfected with wild-type or mutant HRE-luciferase reporter and cotransfected with renilla construct 24 hours after being exposed to $2.5 \% \mathrm{O}_{2}$ hypoxia, treated with $125 \mu \mathrm{mol} / \mathrm{L}$ $\mathrm{CoCl}_{2}$, or left untreated under normoxia. Data shown as fold induction over normoxia expression levels ( $n \geq 4$ replicate experiments).

der hypoxia as well (Figure 1,A-B). Hypoxia dose response showed that $\mathrm{HIF-1} \alpha$ in IPAH-ECs expression was greater than controls at any oxygen tension (paired $t$-test, $P=0.02)$. Consistent with greater $\mathrm{HIF}-1 \alpha$ expression, IPAH-ECs $(n=3)$ had greater HRE-luciferase reporter activation than control cells $(n=3)$ under normoxia (control: $1.00 \pm 0.18 \mathrm{vs}$. IPAH: $1.95 \pm 0.35$, normalized fold induction, $n \geq 8$ replicate experiments, Wilcoxon 1-way test, $P<0.05$ ), under $2.5 \% \mathrm{O}_{2}$ (controls: $1.24 \pm 0.22$ vs. IPAH: $2.48 \pm 0.26$, normalized fold induction, $t$-test, $P=$ 0.01 ) or hypoxia-mimic $\mathrm{CoCl}_{2}$ (controls: $1.67 \pm 0.24$ vs. IPAH: $3.02 \pm 0.37$, normalized fold induction, $n=8$ replicate experiments, $t$-test, $P=0.009$ ) (Figure $1 \mathrm{C}$ ). These results were consistent with the finding of increased expression of HIF-1 $\alpha$ in intimal cells of remodeled large muscular arteries and in cells lining vascular slits in plexiform lesions (previously shown to represent endothelial cells ${ }^{32}$ ) in IPAH lungs, when compared with pulmonary artery intima of normal lungs (Figures 2, A-C and Supplemental Figure S1 at http://ajp.amjpathol.org). Consistent with the finding of increased expression and activity of $\mathrm{HIF}-1 \alpha$ in IPAH pulmonary arteries (which have also been shown to co-express its co-activator partner, $\mathrm{HIF}-1 \beta^{13}$ ), we detected expression of the HIF-1 $\alpha$ target gene CAIX ${ }^{33}$ in intimal cells lining IPAH pulmonary arteries (Figures 2, D-F and Supplemental Figure S1 at http://ajp.amjpathol.org).

The greater expression of HIF- $1 \alpha$ in IPAH-ECs was not due to different expression of prolyl hydroxylase-2 (Figure 3A) or VHL tumor suppressor protein (Supplemental Figure S2 at http://ajp.amjpathol.org). Consistent with these results, $\mathrm{VHL}$ gene promoter was not methylated in IPAH-ECs as compared with control ECs when assayed 

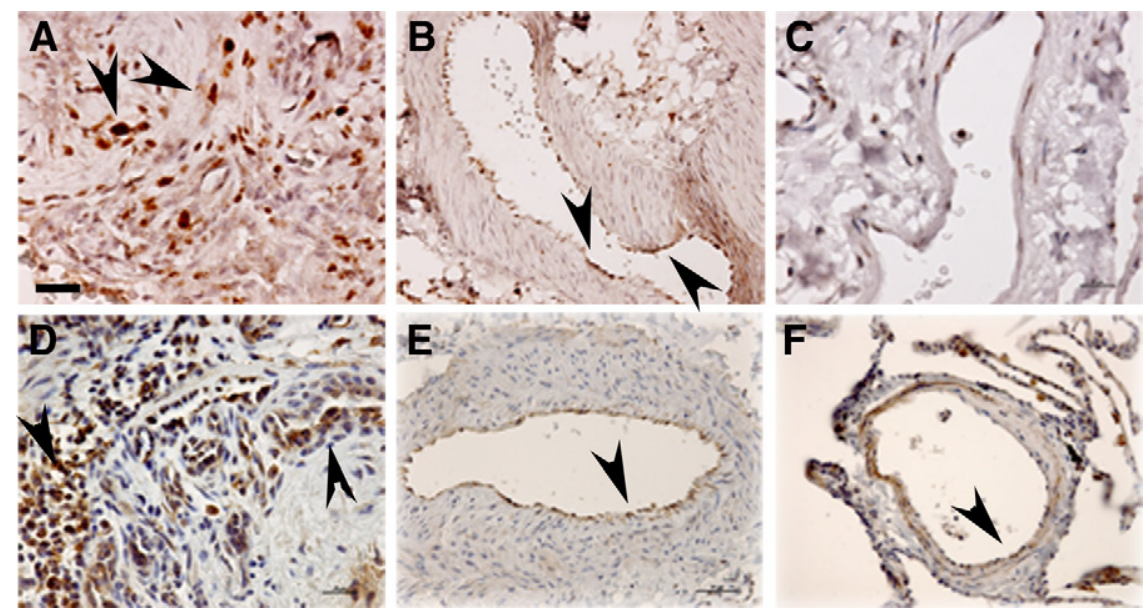

Figure 2. Expression of HIF- $1 \alpha$ and its transcriptional target CAIX in IPAH plexiform lesions and remodeled pulmonary arteries. Note increased expression of HIF- $1 \alpha$ in cells forming the vascular slits in IPAH plexiform lesions (A, arrowheads) and intimal cells lining the remodeled pulmonary arteries (B, arrowheads), when compared with intima of a normal pulmonary artery (C). This pattern of HIF- $1 \alpha$ expression
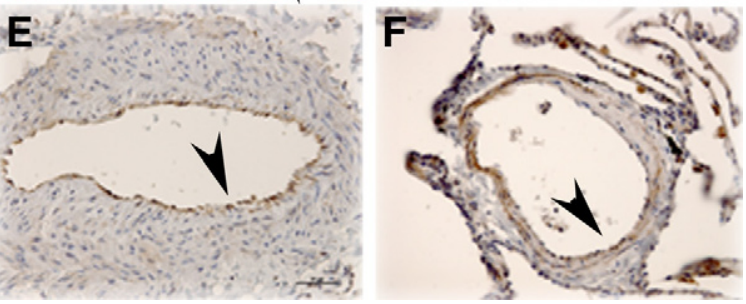
correlated with expression of its transcriptiona target CAIX in an IPAH plexiform lesion (D arrowheads) and pulmonary artery intima (E arrowhead) when compared with a normal pulmonary artery (F, arrowhead). Scale bars $25 \mu \mathrm{m}(\mathbf{A}, \mathbf{D}, \mathbf{E}) ; 50 \mu \mathrm{m}(\mathbf{B}, \mathbf{C}, \mathbf{F})$. Images representative of overall five IPAH and five normal lungs tested.

by bisulfite DNA modification followed by PCR with methylation-specific primers (data not shown).

\section{Lower SOD Expression and Activity Is Related to Higher HIF Activation in IPAH-ECs}

Previous studies identified enhanced oxidative stress, ${ }^{22}$ increased perivascular inflammation, 32,34 and low SOD activity in IPAH lungs. ${ }^{22,35}$ Consistent with these findings, we observed that IPAH-ECs had decreased MnSOD protein expression and overall SOD activity (Figure 3, A-C).

A
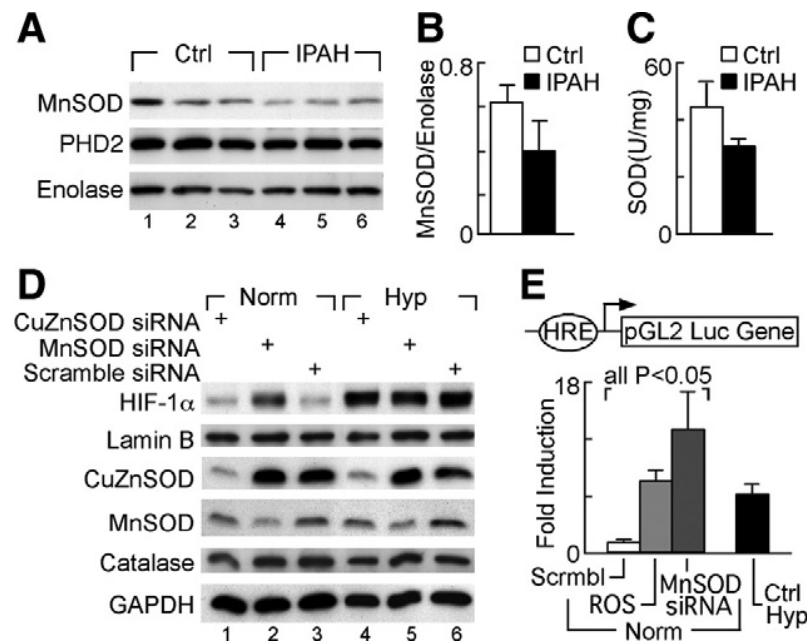

$\mathrm{E}$
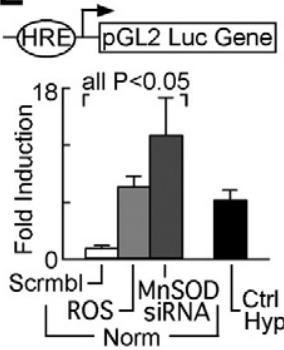

Figure 3. Reduction of MnSOD and SOD activity in IPAH-ECs and regulation of HIF- $1 \alpha$ expression by MnSOD in HUVECs. A-B: Western blot analysis of MnSOD and prolyl hydroxylase 2 protein expression in whole cell extracts of IPAH $(n=5)$ and control pulmonary artery ECs $(n=3)$, normalized by enolase expression (one-way analysis of variance, $P=0.0374$ ). C: SOD activity $(\mathrm{U} / \mathrm{mg})$ is reduced in pulmonary arterial hypertension $(n=5)$, as compared with control pulmonary artery ECs $(n=3)$ (one way analysis of variance, $P=0.0275$ ). D: HIF-1 $\alpha$ expression measured by Western blot of nuclear extracts of HUVECs transiently transfected with MnSOD siRNA, CuZnSOD, or scramble siRNA exposed to $2.5 \% \mathrm{O}_{2}$ (Hyp) or normoxia for 4 hours, normalized for nuclear lamin B. MnSOD, CuZnSOD, and catalase protein expression were evaluated in cytosolic fractions, and normalized for cytosolic glyceraldehyde phosphate dehydrogenase. E: HRE activity in HUVECs transiently transfected with wild-type HRE-luciferase reporter and renilla, and either cotransfected with MnSOD siRNA or scramble siRNA (Scrmbl), or treated with pyrogallol (ROS) for 24 hours under normoxia (Norm). Positive controls consisted of HUVECs exposed to $2.5 \% \mathrm{O}_{2}$ for 24 hours (Ctrl Hyp).
Since MnSOD is both necessary and sufficient to suppress activation of HIF- $1 \alpha$ by hypoxia, ${ }^{36,37}$ we addressed the mechanistic link between decreased MnSOD and increased HIF- $1 \alpha$ levels. MnSOD knockdown by siRNA, but not CuZnSOD siRNA or scrambled siRNA, resulted in increased HIF-1 $\alpha$ expression in normoxic HUVEC. Under hypoxia, HIF- $1 \alpha$ accumulation in HUVEC was not influenced by CuZnSOD knockdown (Figure 3D). Similarly, HRE-luciferase activation in normal pulmonary artery ECs was increased by MnSOD knockdown, as well as by treatment with pyrogallol treatment, which generates intracellular reactive oxygen species (ROS) (all comparisons $P<0.05$ ) (Figure $3 \mathrm{E}$ ).

\section{HIF-1 $\alpha$ Expression in IPAH-ECs Is Modulated by Nitric Oxide}

ROS and NO may influence HIF- $1 \alpha$ stability. ${ }^{14,38,39}$ Pulmonary and total body $\mathrm{NO}$ are lower in IPAH patients, as compared with healthy controls ${ }^{17-21}$ and IPAH-ECs produce lower total amounts of $\mathrm{NO}$ products than control cells in vitro. ${ }^{15,21}$ Since SODs modulate consumption of $\mathrm{NO}$ by superoxide and control the bioavailability of free $\mathrm{NO},{ }^{35}$ we postulated that lower MnSOD expression may consequently lead to low bioavailable NO in IPAH-ECs. Indeed, HUVECs in which the SODs were knocked down by RNA interference had reduced NO production measured as nitrite in media overlying cells $\left(\mathrm{NO}_{2}^{-}[\mathrm{nM}]\right.$ : scramble siRNA, $108 \pm 4$; MnSOD siRNA $72 \pm 12$; CuZnSOD siRNA $47 \pm 1$; one-way analysis of variance, $P=0.02$ ). Although abrogation of both MnSOD and CuZnSOD reduced NO production, only MnSOD knockdown increased HIF- $1 \alpha$ expression in normal cells (Figure $3 \mathrm{E}$ ). These results suggest that the mitochondrial MnSOD, which influences levels of mitochondrial ROS and/or NO bioavailability, might be mechanistically implicated in the enhanced HIF- $1 \alpha$ expression in IPAH-ECs.

To test if $\mathrm{NO}$ affects HIF- $1 \alpha$ expression in IPAH-ECs, $\mathrm{HIF}-1 \alpha$ expression was analyzed in cells after treatment with a range of different concentrations of the $\mathrm{NO}$ donor detaNO. HIF- $1 \alpha$ induction by high-levels of detaNO under normoxia was also greater in IPAH-ECs than in con- 
A

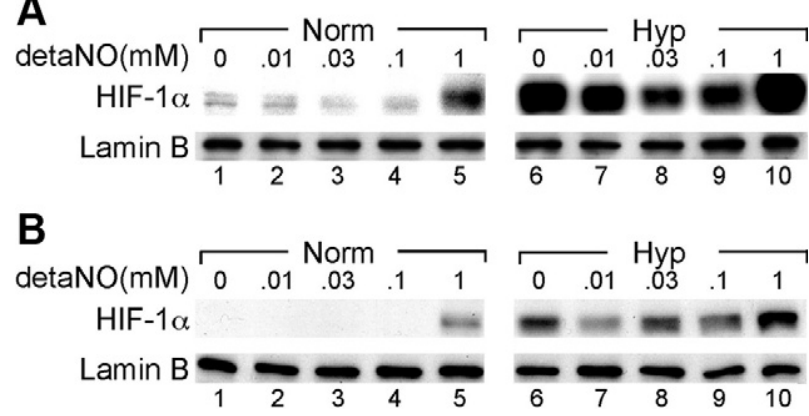

Figure 4. Nitric oxide modulates HIF- $1 \alpha$ expression in IPAH-ECs. IPAH (A) and control (B) pulmonary artery ECs were treated with the NO donor $\operatorname{detaNO}(10 \mu \mathrm{mol} / \mathrm{L}, 30 \mu \mathrm{mol} / \mathrm{L}, 100 \mu \mathrm{mol} / \mathrm{L}$, and $1 \mathrm{mmol} / \mathrm{L})$ or vehicle under normoxia (Norm) or $2.5 \% \mathrm{O}_{2}$ (Hyp). HIF- $1 \alpha$ expression was determined in nuclear extracts, normalized for expression of lamin-B.

trol cells (Figure 4, A-B). As previously reported with non-EC cultured cells, ${ }^{40}$ low levels of $\mathrm{NO}$ (ie, $10 \mu \mathrm{mol} / \mathrm{L}-$ $100 \mu \mathrm{mol} / \mathrm{L}$ detaNO) reduced normoxic and hypoxiainduced HIF-1 $\alpha$ accumulation in IPAH-ECs (Figure 4A). These findings suggest that loss of $\mathrm{NO}$ production (as by decreased EC NO synthesis ${ }^{21}$ ) might result in loss of inhibition of HIF-1 $\alpha$ under normoxia.

\section{Knockdown of HIF-1 $\alpha$ Increases Mitochondria Numbers in IPAH-ECs in Vitro}

The proliferative phenotype of ECs in IPAH has been further substantiated by the findings that IPAH-ECs have decreased cellular respiration and lower numbers of mi- tochondria than control cells, which can be rescued by increase in NO bioavailability. ${ }^{15}$ We tested whether $\mathrm{HIF}-1 \alpha$ expression lies downstream of $\mathrm{NO}$ and therefore contributes to the shift to anaerobic metabolism using an anti-HIF-1 $\alpha$ miRNA construct, which resulted in $\sim 75 \%$ inhibition of HRE-luciferase activity in cells exposed to cobalt or hypoxia. Using Mitotracker Red 580 and confocal laser-scanning microscopy to evaluate changes in mitochondria, we found that IPAH-ECs have approximately half the number of mitochondria as control cells (relative fluorescence: IPAH, $0.53 \pm 0.29$ vs. Ctrl $1.00 \pm$ 0.21 ; $t$-test, $P=0.01)$. These findings were also supported by the assessment of mitochondria DNA (Figure $5 \mathrm{C}$ ) and expression of mitochondria complex III-2 and cytochrome $c$ (Figure 5D) in representative IPAH-ECs, when compared with control ECs. These results are in line with our prior documentation of decreased mitochondria DNA based on quantitative PCR and on electron microscopy. ${ }^{15} \mathrm{HIF}-1 \alpha$ miRNA increased the mitochondria numbers, mtDNA and mitochondrial proteins Complex III-2, and cytochrome $c$ in IPAH-ECs (Figure 5, A-D). We previously showed that mitochondria numbers increase with supplementation of $\mathrm{NO}$ donor (with $125 \mathrm{mmol} / \mathrm{L}$ detaNO). ${ }^{15}$ As shown above, a similar concentration of this $\mathrm{NO}$ donor also decreased $\mathrm{HIF}-1 \alpha$ expression in the IPAH-ECs (Figure 4A). Taken together, this suggests that the effect of $\mathrm{NO}$ donor on mitochondria numbers might be via HIF-1 $\alpha$ inhibition. To rule out any potential effect of HIF- $1 \alpha$ knockdown on NO production by the cells, we measured nitrite in supernatants. Nitrite levels in media

\section{A No DNA Anti-HIF miRNA Neg miRNA}
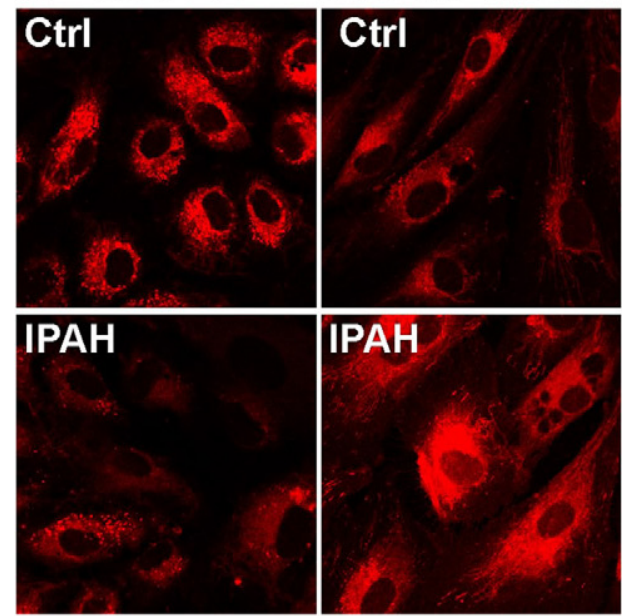

B

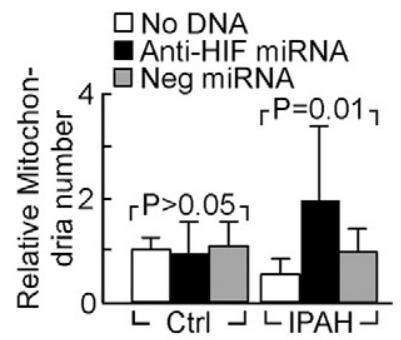

C

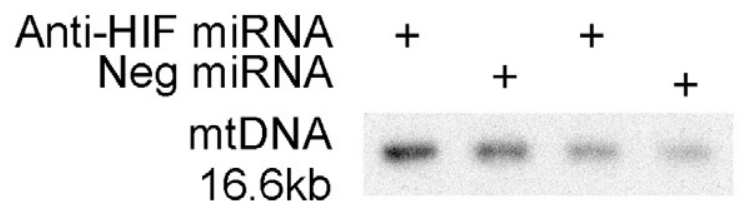

Figure 5. Knockdown HIF- $1 \alpha$ by miRNA increases mitochondria in IPAH-pulmonary artery ECs. A and B: Mitochondria were quantified with Mitotracker Red 580 followed by confocal laser-scanning microscopy in IPAH and control pulmonary artery ECs transiently transfected with anti HIF-1 $\alpha$ miRNA, negative control miRNA (Neg miRNA), or left untransfected (No DNA). C: Southern analysis of mtDNA content in representative IPAH-ECs and control endothelial cells transfected with anti-HIF- $1 \alpha$ miRNA or scrambled miRNA D: Expression of eNOS, mitochondrial complex III-2, and cytochrome $c$ protein of representative IPAH-EC and control endothelial cells transfected with anti-HIF-1 $\alpha$ miRNA or scrambled miRNA assessed by Western blot analysis.

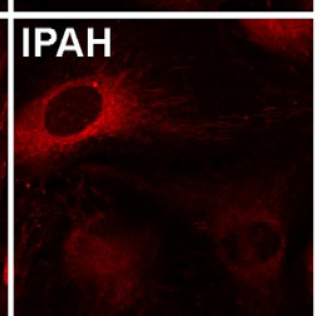
$16.6 \mathrm{~kb}$
D

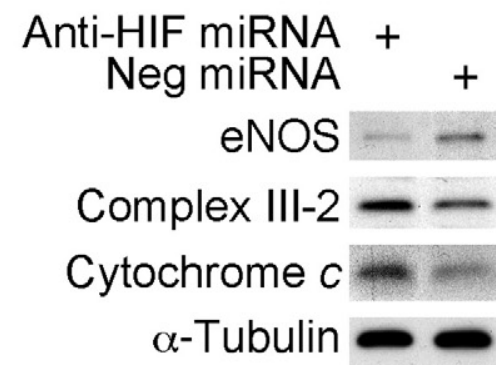


overlying cells were similar with anti-HIF- $1 \alpha$ miRNA or control vector transfected ( $t$-test, $P>0.05$ ), despite that eNOS expression in IPAH-ECs was HIF-dependent as eNOS protein levels were reduced by anti-HIF- $1 \alpha$ miRNA ${ }^{41}$ (Figure 5D).

\section{Discussion}

Because of its central role in the cancerous cell shift to a glycolytic metabolism, $\mathrm{HIF}-1 \alpha$ expression is one of the fundamental mechanisms in the neoplastic cell survival and proliferation. Furthermore, HIF- $1 \alpha$ also controls energy metabolism, erythropoiesis, vasomotor tone, and angiogenesis. ${ }^{9}$ Here, we show that IPAH-ECs have greater HIF- $1 \alpha$ accumulation and HRE activation than controls under normoxia and hypoxia, which parallel the findings that expression of HIF- $1 \alpha$ and its transcriptional target CAIX are increased in ECs of lesional vessels, including the plexiform lesions of IPAH lungs in vivo. The up-regulation of HIF- $1 \alpha$ in IPAH-ECs is potentially dependent on the down-regulation of MnSOD and decreased levels of NO. Our data also indicate that a decrease in MnSOD expression in normal ECs suffices to increase the expression of HIF- $1 \alpha$ under normoxia. In aggregate, our findings therefore point to a link between oxidative stress due to down-regulation of MnSOD expression and the associated lower levels of $\mathrm{NO}$ and up-regulation of $\mathrm{HIF}-1 \alpha$ in IPAH-ECs. Excessive ROS generation and loss of MnSOD activity has been documented in human pulmonary arterial hypertension, whether idiopathic or associated with other lung diseases, and has been linked to HIF activation in model systems, ${ }^{14,18,22,25,35,42}$ therefore potentially contributing to pulmonary vascular remodeling.

The well-described deficiency of NO in patients with IPAH and pulmonary arterial hypertension associated with collagen vascular disease ${ }^{18-20}$ is therapeutically targeted by the use of the phosphodiesterase inhibitor sildenafil. We have previously shown that cultured IPAHECs have decreased NO levels, ${ }^{21}$ which contribute to the decrease in mitochondria numbers and glycolytic shift previously documented in these cells. ${ }^{15}$ Under normoxia, $\mathrm{NO}$ and/or its reaction products mimic hypoxia, leading to HIF- $1 \alpha$ protein stabilization, HIF-1 dimer formation, and gene induction. ${ }^{43}$ Several mechanism(s) of accumulation of $\mathrm{HIF}-1 \alpha$ by high levels of $\mathrm{NO}$ under normoxia have been proposed, including (i) NO inhibition of the terminal enzyme cytochrome $\mathrm{c}$ oxidase (complex IV) in the mitochondria, which would lead to a state of mitochondrial 'hypoxia'33 or (ii) NO reaction with superoxide to form $\mathrm{ONOO}^{-}$which may result in S-nitrosylation of thiol groups in the HIF- $1 \alpha$ and stabilization of HIF- $1 \alpha,{ }^{39,40,44-47}$ and/or (iii) reactive species inhibition of enzymes responsible for HIF- $1 \alpha$ hydroxylation. ${ }^{47-50}$ In contrast, low levels of NO reduce hypoxia-induced $\mathrm{HIF}-1 \alpha$ accumulation and $\mathrm{HIF}-1$ gene induction. ${ }^{51}$ Under hypoxia, the blockade of cellular respiration by $\mathrm{NO}$ enables higher overall intracellular $\mathrm{O}_{2}$ availability for increased degradation of $\mathrm{HIF}-1 \alpha{ }^{50,52}$ Here, we found that $\mathrm{HIF}-1 \alpha$ induction was greater in IPAH than control ECs by supplementation with high levels of NO. On the other hand, low levels of the NO donor reduced hypoxia-induced $\mathrm{HIF}-1 \alpha$ accumulation and also reduced the HIF- $1 \alpha$ expressed under normoxia in IPAHECs. Thus, while decreased NO synthesis has been shown to account for decreased mitochondria numbers and metabolic shift, ${ }^{15}$ we postulated that the downstream mechanisms mediating these effects may involve HIF- $1 \alpha$.

The mitochondrial MnSOD plays a central role in enzymatic scavenging of superoxide. Mitochondria are the largest producer of ROS through the process of cellular respiration in which mitochondria catalyze one-electron reduction of oxygen to superoxide radical followed by formation of hydrogen peroxide, in addition to the fourelectron reduction of oxygen to water. ${ }^{53}$ We confirmed that the lower SOD activity in IPAH-ECs as compared with control cells was probably related to lower MnSOD protein. The lower MnSOD expression could be due to the lower numbers of mitochondria in IPAH cells ${ }^{15}$ or downregulation of MnSOD gene due to AKT-dependent phosphorylation of FOXO transcription factors. ${ }^{13,54}$ We further documented that $\mathrm{HIF}-1 \alpha$ protein accumulated in normoxic HUVECs treated with MnSOD siRNA and that HREluciferase activation increased with MnSOD siRNA or pyrogallol treatment (which generates intracellular ROS). Notwithstanding the complexity of the mechanisms underlying pathological NO deficiency, ${ }^{15,18,21}$ our data supports that lower MnSOD controls the accumulation of $\mathrm{HIF}-1 \alpha$ protein and may be consequential to low NO production by IPAH cells.

There is growing evidence of the shared features between severe pulmonary hypertension and neoplastic processes. Genetic instability, a characteristic hallmark of cancer, has also been documented in IPAH lungs. ${ }^{55}$ We have evidence of significant somatic gene losses in pulmonary hypertensive cells (Aldred et al, submitted). The link between genetic instability and $\mathrm{HIF}-1 \alpha$ activation was recently documented in an animal model of Kaposi's sarcoma, also a vascular proliferative process sharing many of the features abnormal angiogenesis seen in $\mathrm{PH}$ lungs. 56,57

Taken together, accumulating evidence from our group and others identifies that abnormalities of $\mathrm{NO}$ production and reduced cellular respiration/mitochondria function coupled to increased glycolysis are universal hallmarks of $\mathrm{PH}$ across species, including murine, rodent, avian, and human. ${ }^{14,15,58,59}$ Here, increased HIF- $1 \alpha$ expression is mechanistically linked to both the alterations of $\mathrm{NO}$ and the ensuing metabolic changes present in pulmonary arterial hypertension.

Our studies are clinically relevant as they provide the translational framework to understand the recent successes of pharmacological strategies that target cellular utilization of mitochondria respiration vis-a-vis glycolysis, including imatinib ${ }^{60}$ (an inhibitor of PDGF, c-kit receptors, and also hexokinases ${ }^{61}$ ), the nonspecific inhibitors of HIF-1 $\alpha$ 2-metoxyestradiol ${ }^{62}$ or cyclosporine-A, ${ }^{63}$ and the pyruvate kinase inhibitor dichloroacetate. ${ }^{64}$ Novel therapies aimed at glycolytic pathways and/or HIF-1 signaling may control vascular cell growth programs shared by endothelial and smooth muscle cells that contribute to occlusive vascular lesions in this untreatable disease. 


\section{Note Added In Proof}

Since acceptance of this manuscript, we have been able to detect HIF- $1 \alpha$ by immunohistochemistry and the endothelial cell marker Factor VIII-related antigen by immunofluorescence in the lung sections of two patients with IPAH. Our approach allowed the acquisition of sequential images, one in bright field showing HIF- $\alpha$ expression by bright field (as shown in Figure 2) and another depicting expression of Factor VIII-related antigen by immunofluorescence in the same vascular lesions (Supplemental Figure S3, available online at http://ajp.amjpathol.org). These findings confirm our initial assertion that endothelial cells express HIF-1 $\alpha$ in IPAH lungs.

\section{Acknowledgments}

We thank Dr. M. Celeste Simon for the generous gifts of wild-type HRE-luciferase reporter construct and mutant HRE-luciferase reporter construct and Dr. Gregg L. Semenza for the detailed methods for nuclear extract preparation.

\section{References}

1. Lee SD, Shroyer KR, Markham NE, Cool CD, Voelkel NF, Tuder RM: Monoclonal endothelial cell proliferation is present in primary but not secondary pulmonary hypertension. J Clin Invest 1998, 101:927-934

2. Deng Z, Morse JH, Slager SL, Cuervo N, Moore KJ, Venetos G, Kalachikov S, Cayanis E, Fischer SG, Barst RJ, Hodge SE, Knowles $\mathrm{JA}$ : Familial primary pulmonary hypertension (gene $\mathrm{PPH} 1$ ) is caused by mutations in the bone morphogenetic protein receptor-II gene. Am J Hum Genet 2000, 67:737-744

3. The International PPH Consortium, Lane KB, Machado RD, Pauciulo.M.W., Thompson JR, Philips III JA, Loyd JE, Nichols WC, Trembath RC: Heterozygous germline mutations in BMPR2 encoding a TGF-B receptor cause familiar pulmonary hypertension. Nat Genet 2000, 26:81-84

4. Voelkel NF, Cool CD, Lee SD, Wright L, Geraci MW, Tuder RM: Primary pulmonary hypertension between inflammation and cancer. Chest 1999, 114:225S-230S

5. Rai PR, Cool CD, King JAC, Stevens T, Burns N, Winn RA, Kasper M, Voelkel NF: The cancer paradigm of severe pulmonary arterial hypertension. Am J Respir Crit Care Med 2008, 178:558-564

6. Yu AY, Shimoda LA, Iyer NV, Huso DL, Sun X, McWilliams R, Beaty T, Sham JS, Wiener CM, Sylvester JT, Semenza GL: Impaired physiological responses to chronic hypoxia in mice partially deficient for hypoxia-inducible factor 1 alpha. J Clin Invest 1999, 103:691-696

7. Brusselmans K, Compernolle V, Tjwa M, Wiesener MS, Maxwell PH, Collen D, Carmeliet P: Heterozygous deficiency of hypoxia-inducible factor-2 $\alpha$ protects mice against pulmonary hypertension and right ventricular dysfunction during prolonged hypoxia. J Clin Invest 2003, 111:1519-1527

8. Semenza GL: Life with oxygen. Science 2007, 318:62-64

9. Semenza GL: Targeting HIF-1 for cancer therapy. Nat Rev Cancer 2003, 3:721-732

10. Warburg O, Posener K, Negelein E: Ueber den Stoffwechsel der Carcinomzelle. Biochem 1924, Z152:319-344

11. Compernolle V, Brusselmans $K$, Acker $T$, Hoet $P$, Tjwa M, Beck $H$, Plaisance S, Dor Y, Keshet E, Lupu F, Nemery B, Dewerchin M, Van Veldhoven P, Plate K, Moons L, Collen D, Carmeliet P: Loss of HIF-2[alpha] and inhibition of VEGF impair fetal lung maturation, whereas treatment with VEGF prevents fatal respiratory distress in premature mice. Nat Med 2002, 8:702-710

12. Tuder RM, Flook BE, Voelkel NF: Increased gene expression for VEGF and the VEGF receptors KDR/Flk and Flt in lungs exposed to acute or to chronic hypoxia. Modulation of gene expression by nitric oxide. J Clin Invest 1995, 95:1798-1807

13. Tuder RM, Chacon M, Alger LA, Wang J, Taraseviciene-Stewart L, Kasahara Y, Cool CD, Bishop AE, Geraci MW, Semenza GL, Yacoub M, Polak JM, Voelkel NF: Expression of angiogenesis-related molecules in plexiform lesions in severe pulmonary hypertension: evidence for a process of disordered angiogenesis. J Pathol 2001, 195:367-374

14. Bonnet S, Michelakis ED, Porter CJ, ndrade-Navarro MA, Thebaud B, Bonnet S, Haromy A, Harry G, Moudgil R, McMurtry S, Weir EK, Archer SL: An abnormal mitochondrial-hypoxia inducible factor-1 alpha-Kv channel pathway disrupts oxygen sensing and triggers pulmonary arterial hypertension in fawn hooded rats - similarities to human pulmonary arterial hypertension. Circulation 2006, 113:2630-2641

15. Xu W, Koeck T, Lara AR, Neumann D, DiFilippo FP, Koo M, Janocha AJ, Masri FA, Arroliga AC, Jennings C, Dweik RA, Tuder RM, Stuehr DJ, Erzurum SC: Alterations of cellular bioenergetics in pulmonary artery endothelial cells. Proc Natl Acad Sci USA 2007, 104:1342-1347

16. Masri FA, Xu W, Comhair SA, Asosingh K, Koo M, Vasanji A, Drazba $J$, nand-Apte B, Erzurum SC: Hyperproliferative apoptosis-resistant endothelial cells in idiopathic pulmonary arterial hypertension. Am J Physiol Lung Cell Mol Physiol 2007, 293:L548-L554

17. Girgis RE, Champion HC, Diette GB, Johns RA, Permutt S, Sylvester JT: Decreased exhaled nitric oxide in pulmonary arterial hypertension: response to bosentan therapy. Am J Respir Crit Care Med 2005, 172:352-357

18. Kaneko FT, Arroliga AC, Dweik RA, Comhair SA, Laskowski D, Oppedisano R, Thomassen MJ, Erzurum SC: Biochemical reaction products of nitric oxide as quantitative markers of primary pulmonary hypertension. Am J Respir Crit Care Med 1998, 158:917-923

19. Machado RF, Londhe Nerkar MV, Dweik RA, Hammel J, Janocha A, Pyle J, Laskowski D, Jennings C, Arroliga AC, Erzurum SC: Nitric oxide and pulmonary arterial pressures in pulmonary hypertension. Free Radic Biol Med 2004, 37:1010-1017

20. Ozkan M, Dweik RA, Laskowski D, Arroliga AC, Erzurum SC: High levels of nitric oxide in individuals with pulmonary hypertension receiving epoprostenol therapy. Lung 2001, 179:233-243

21. Xu W, Kaneko FT, Zheng S, Comhair SA, Janocha AJ, Goggans T, Thunnissen FB, Farver C, Hazen SL, Jennings C, Dweik RA, Arroliga AC, Erzurum SC: Increased arginase II and decreased NO synthesis in endothelial cells of patients with pulmonary arterial hypertension. FASEB J 2004, 18:1746-1748

22. Bowers R, Cool C, Murphy RC, Tuder RM, Hopken MW, Flores SC Voelkel NF: Oxidative stress in severe pulmonary hypertension. Am J Respir Crit Care Med 2004, 169:764-769

23. Grobe AC, Wells SM, Benavidez E, Oishi P, Azakie A, Fineman JR, Black SM: Increased oxidative stress in lambs with increased pulmonary blood flow and pulmonary hypertension: role of NADPH oxidase and endothelial NO synthase. Am J Physiol-Lung Cell MPH 2006, 290:L1069-L1077

24. Liu JQ, Zelko IN, Erbynn EM, Sham JS, Folz RJ: Hypoxic pulmonary hypertension: role of superoxide and NADPH oxidase (gp91phox). Am J Physiol Lung Cell Mol Physiol 2006, 290:L2-L10

25. Wedgwood S, Black SM: Role of reactive oxygen species in vascular remodeling associated with pulmonary hypertension. Antioxid Redox Signal 2003, 5:759-769

26. Simonneau G, Galie N, Rubin LJ, Langleben D, Seeger W, Domenighetti G, Gibbs S, Lebrec D, Speich R, Beghetti M, Rich S, Fishman A: Clinical classification of pulmonary hypertension. J Am Coll Cardiol 2004, 43:5S-12S

27. Simonneau G, Robbins IM, Beghetti M, Channick RN, Delcroix M, Denton CP, Elliott CG, Gaine SP, Gladwin MT, Jing ZC, Krowka MJ, Langleben D, Nakanishi N, Souza R: Updated clinical classification of pulmonary hypertension. J Am Coll Cardiol 2009, 54:S43-S54

28. Richter A, Yeager ME, Zaiman A, Cool CD, Voelkel NF, Tuder RM: Impaired transforming growth Factor $\beta$ signaling in idiopathic pulmonary arterial hypertension. Am J Respir Crit Care Med 2004, 170:1340-1348

29. Herman JG, Graff JR, Myohanen S, Nelkin BD, Baylin SB: Methylation-specific PCR: a novel PCR assay for methylation status of $\mathrm{CpG}$ islands. Proc Natl Acad Sci USA 1996, 93:9821-9826

30. Arsham AM, Plas DR, Thompson CB, Simon MC: Phosphatidylinositol 3-kinase/Akt signaling is neither required for hypoxic stabilization of 
HIF-1 alpha nor sufficient for HIF-1-dependent target gene transcription. J Biol Chem 2002, 277:15162-15170

31. Comhair SAA, Xu W, Ghosh S, Thunnissen FBJM, Almasan A, Calhoun WJ, Janocha AJ, Zheng L, Hazen SL, Erzurum SC: Superoxide dismutase inactivation in pathophysiology of asthmatic airway remodeling and reactivity. Am J Pathol 2005, 166:663-674

32. Tuder RM, Groves BM, Badesch DB, Voelkel NF: Exuberant endothelial cell growth and elements of inflammation are present in plexiform lesions of pulmonary hypertension. Am J Pathol 1994, 144:275-285

33. Wykoff CC, Beasley NJ, Watson PH, Turner KJ, Pastorek J, Sibtain A, Wilson GD, Turley H, Talks KL, Maxwell PH, Pugh CW, Ratcliffe PJ, Harris AL: Hypoxia-inducible expression of tumor-associated carbonic anhydrases. Cancer Res 2000, 60:7075-7083

34. Dorfmuller P, Perros F, Balabanian K, Humbert M: Inflammation in pulmonary arterial hypertension. Eur Respir J 2003, 22:358-363

35. Masri FA, Comhair SA, Dostanik-Larson I, Kaneko FT, Dweik RA, Arroliga AC, Erzurum SC: Deficiency of lung antioxidants in idiopathic pulmonary arterial hypertension. Clin Transl Sci 2008, 1:99-106

36. Kaewpila S, Venkataraman S, Buettner GR, Oberley LW: Manganese superoxide dismutase modulates hypoxia-inducible factor- 1 alpha induction via superoxide. Cancer Res 2008, 68:2781-2788

37. Wang M, Kirk JS, Venkataraman S, Domann FE, Zhang HJ, Schafer FQ, Flanagan SW, Weydert CJ, Spitz DR, Buettner GR, Oberley LW: Manganese superoxide dismutase suppresses hypoxic induction of hypoxia-inducible factor-1alpha and vascular endothelial growth factor. Oncogene 2005, 24:8154-8166

38. Chandel NS, McClintock DS, Feliciano CE, Wood TM, Melendez JA, Rodriguez AM, Schumacker PT: Reactive oxygen species generated at mitochondrial complex III stabilize hypoxia-inducible factor-1alpha during hypoxia: a mechanism of $\mathrm{O}_{2}$ sensing. J Biol Chem 2000, 275:25130-25138

39. Mateo J, Garcia-Lecea M, Cadenas S, Hernandez C, Moncada S: Regulation of hypoxia-inducible factor-1alpha by nitric oxide through mitochondria-dependent and -independent pathways. Biochem J 2003, 376:537-544

40. Murphy MP: Does interplay between nitric oxide and mitochondria affect hypoxia-inducible transcription factor- 1 activity? Biochem $J$ 2003, 376:e5-e6

41. Coulet F, Nadaud S, Agrapart M, Soubrier F: Identification of hypoxiaresponse element in the human endothelial nitric-oxide synthase gene promoter. J Biol Chem 2003, 278:46230-46240

42. Cracowski JL, Cracowski C, Bessard G, Pepin JL, Bessard J, Schwebel C, Stanke-Labesque F, Pison C: Increased lipid peroxidation in patients with pulmonary hypertension. Am J Respir Crit Care Med 2001, 164:1038-1042

43. Kimura H, Weisz A, Kurashima Y, Hashimoto K, Ogura T, D'Acquisto F, Addeo R, Makuuchi M, Esumi H: Hypoxia response element of the human vascular endothelial growth factor gene mediates transcriptional regulation by nitric oxide: control of hypoxia-inducible factor- 1 activity by nitric oxide. Blood 2000, 95:189-197

44. Palmer LA, Gaston B, Johns RA: Normoxic stabilization of hypoxiainducible factor- 1 expression and activity: redox-dependent effect of nitrogen oxides. Mol Pharmacol 2000, 58:1197-1203

45. Metzen E, Zhou J, Jelkmann W, Fandrey J, Brune B: Nitric oxide impairs normoxic degradation of HIF-1alpha by inhibition of prolyl hydroxylases. Mol Biol Cell 2003, 14:3470-3481

46. Callapina M, Zhou J, Schmid T, Kohl R, Brune B: NO restores HIF-1 alpha hydroxylation during hypoxia: role of reactive oxygen species. Free Rad Biol Med 2005, 39:925-936

47. Agani FH, Pichiuli P, Chavez JC, LaManna JC: The role of mitochon- dria in the regulation of the hypoxia-inducible factor 1 expression during hypoxia. J Biol Chem 2000, 275:35863-35867

48. Chandel NS, Maltepe E, Goldwasser E, Mathieu CE, Simon MC, Schumacker PT: Mitochondrial reactive oxygen species trigger hypoxiainduced transcription. Proc Natl Acad Sci USA 1998, 95:11715-11720

49. Schroedl C, McClintock DS, Budinger GRS, Chandel NS: Hypoxic but not anoxic stabilization of HIF-1 alpha requires mitochondrial reactive oxygen species. Am J Physiol -Lung Cell MPH 2002, 283:L922-L931

50. Hagen T, Taylor CT, Lam F, Moncada S: Redistribution of intracellular oxygen in hypoxia by nitric oxide: effect on HIF1alpha. Science 2003, 302:1975-1978

51. Liu Y, Christou H, Morita T, Laughner E, Semenza GL, Kourembanas $\mathrm{S}$ : Carbon monoxide and nitric oxide suppress the hypoxic induction of vascular endothelial growth factor gene via the 5 ' enhancer. J Biol Chem 1998, 273:15257-15262

52. Quintero M, Colombo SL, Godfrey A, Moncada S: Mitochondria as signaling organelles in the vascular endothelium. Proc Natl Acad Sci USA 2006, 103:5379-5384

53. Vinogradov AD, Grivennikova VG: Generation of superoxide-radical by the NADH:ubiquinone oxidoreductase of heart mitochondria. Biochemistry (Mosc) 2005, 70:120-127

54. Li M, Chiu JF, Mossman BT, Fukagawa NK: Down-regulation of manganese-superoxide dismutase through phosphorylation of $\mathrm{FOXO} 3$ by Akt in explanted vascular smooth muscle cells from old rats. J Biol Chem 2006, 281:40429-40439

55. Yeager ME, Halley GR, Golpon HA, Voelkel NF, Tuder RM: Microsatellite instability of endothelial cell growth and apoptosis genes within plexiform lesions in primary pulmonary hypertension. Circ Res 2001, 88:e8-e11

56. Cool CD, Rai MD, Yeager ME, Hernandez-Saavedra D, Serls AE, Bull TM, Geraci MW, Brown KK, Routes JM, Tuder RM, Voelkel NF: Expression of human herpesvirus 8 in primary pulmonary hypertension. N Engl J Med 2003, 349:1113-1122

57. Ma Q, Cavallin LE, Yan B, Zhu S, Duran EM, Wang H, Hale LP, Dong C, Cesarman E, Mesri EA, Goldschmidt-Clermont PJ: Antitumorigenesis of antioxidants in a transgenic Rac1 model of Kaposi's sarcoma. Proc Natl Acad Sci USA 2009, 106:8683-8688

58. Tang Z, Iqbal M, Cawthon D, Bottje WG: Heart and breast muscle mitochondrial dysfunction in pulmonary hypertension syndrome in broilers (Gallus domesticus). Comp Biochem Physiol A Mol Integr Physiol 2002, 132:527-540

59. Cawthon D, Iqbal M, Brand J, McNew R, Bottje WG: Investigation of proton conductance in liver mitochondria of broilers with pulmonary hypertension syndrome. Poult Sci 2004, 83:259-265

60. Ghofrani HA, Seeger W, Grimminger F: Imatinib for the treatment of pulmonary arterial hypertension. N Engl J Med 2005, 353:1412-1413

61. Pelicano H, Martin DS, Xu RH, Huang P: Glycolysis inhibition for anticancer treatment. Oncogene 2006, 25:4633-4646

62. Tofovic SP, Salah EM, Mady HH, Jackson EK, Melhem MF: Estradiol metabolites attenuate monocrotaline-induced pulmonary hypertension in rats. J Cardiovasc Pharmacol 2005, 46:430-437

63. Koulmann N, Novel-Chate V, Peinnequin A, Chapot R, Serrurier B, Simler N, Richard H, Ventura-Clapier R, Bigard X: Cyclosporin A inhibits hypoxia-induced pulmonary hypertension and right ventricle hypertrophy. Am J Respir Crit Care Med 2006, 174:699-705

64. Michelakis ED, McMurtry MS, Wu XC, Dyck JR, Moudgil R, Hopkins TA, Lopaschuk GD, Puttagunta L, Waite R, Archer SL: Dichloroacetate, a metabolic modulator, prevents and reverses chronic hypoxic pulmonary hypertension in rats: role of increased expression and activity of voltage-gated potassium channels. Circulation 2002, 105:244-250 